\title{
ANALISIS KONTEN DAKWAH PADA WEBSITE AHMADSASTRA.COM
}

\author{
Intan $^{1}$, Kamalludin ${ }^{2}$ dan Gunawan Ikhtiono ${ }^{3}$ \\ 1,2 \& 3 Program Studi Komunikasi Penyiaran Islam, Fakultas Agama Islam, Universitas Ibn \\ Khaldun Bogor Jl. Sholeh Iskandar, Kedung Badak, Tanah Sereal, Kota Bogor, Jawa Barat 16162 \\ Email : Intanboruregar@gmail.com
}

\begin{abstract}
Based on the formulation of the problem, the purpose of this study is to determine the background of the establishment of the AhmadSastra.com website and what kind of da' wah content is contained in it. The focus of this research in on the da'wah content presented in the AhmadSastra.com Actual Opinion Rubric as a source of information. The research method used by researchers in this study is a qualitative approach with content analysis methods and Teun Van Dijk discourse analysis theory. During the research, researchers directly observed this website quite intensively. This is done in order to know and understand more closely what kinds of content are usually contained in AhmadSastra.com actual opinion rubric. The result of this research is that the da'wah contentsare dominated by the message of faith and sharia. Moral messages are found only as reinforcement in his articles. Based on the research results, the conten of the da'wah in this rubric is not only about worship. More than that, according to the background of the founding of this website, the message of the author is about invitation messages, appeals, orders, criticism, and quick responses to publicity issues with language that is straightforward, firm, hard, and sometimes leaves spicy messages.
\end{abstract}

Keywords: AhmadSastra.com Websites; Analysis; Da'wah Contents

\begin{abstract}
Abstrak
Berdasarkan rumusan masalah, tujuan dari penelitian ini adalah untuk mengetahui latar belakang berdirinya website AhmadSastra.com dan konten-konten dakwah seperti yang apa yang termuat di dalamnya Fokus dari penelitian ini adalah pada konten dakwah yang tersaji dalam Rubrik Opini Aktual AhmadSastra.com. Metode penelitian yang digunakan peneliti dalam penelitian ini adalah pendekatan kualitatif dengan metode analisis isi dan teori analisis wacana Teun Van Dijk. Selama penelitian berlangung, peneliti mengamati langsung website ini dengan cukup intens. Hal ini dilakukan agar mengetahui dan memahami dengan lebih dekat tentang konten-konten yang seperti apa saja yang biasa tertuang dalam rubrik opini aktual AhmadSasra.com ini. Hasil dari penelitian ini yaitu konten-konten dakwah didominasi oleh pesan akidah dan syariah. Pesan akhlak didapati hanya menjadi penguat atau penghias dalam artikel-artikel rubrik opini AhmadSastra.com. Berdasarkan hasil penelitian, konten-konten dakwah pada rubrik ini, bukan hanya berisikan tentang pesan peribadatan saja. Lebih dari itu, sesuai dengan latar belakang berdirinya website ini, pesan dakwah yang disampaikan penulis adalah tentang pesan-pesan ajakan, himbauan, perintah, kritikan, dan respon cepat atas isu-isu keummatan dengan bahasa yang lugas, tegas, keras, dan terkadang berkesan pedas.
\end{abstract}

Kata Kunci: Website AhmadSastra.com; Analisis; Konten Dakwah

(C)2020 The authors and Komunika. All rights reserved. 


\section{Pendahuluan}

Menjamurnya situs media sosial, menjadikan manusia bak seperti seorang Tuan, yangkebutuhannya akan selalu terlayani. Layaknya seorang raja, manusia era ini, bisa mendapatkan keinginan dan kebutuhannya dengan sangat mudah. Kebutuhan untuk saling berkomunikasi, berbagi, saling memberi informasi, mengedukasi dan memberikan positif narasi adalah hal-hal yang tidak bisa dipisahkan dari tatanan kehidupan manusia.

Untuk itu, salah satu media sosial yang menjadi rujuan dan referensi masyarakat adalah website. Media yang ditemukan oleh Tim Berners Lee ini muncul pada tahun 1990. Awalnya website hanya dijadikan sebagai tempat untuk menyimpan arsip- arsipnya. Kemudian, seiring waktu berjalan, manusia makin berwawasan, dan teknologi pun semakin pada puncak kemajuannya, website kian berkembang. Puncaknya adalah ketika media sosial mengudara di masyarakat.

Media sosial mengepakkan sayapnya melalui jaringan internet. Membuktikan bahwa saat ini, untuk mendapatkan informasi bisa dengan cara yang mudah dan praktis. Dulu, kita disibukkan dengan membaca koran dan majalah hampir setiap pagi hanya untuk mengetahui informasi dan berita-berita terkini. Atau, kita dituntut untuk menonton siaran berita di televisi hanya agar tidak ketinggalan informasi. Hal trersebut berubah ketika media sosial muncul. Saat ini cukup dalam genggaman tangan dan terhubung pada jaringan kita bisa mendapatkan informasiinformasi itu secara mudah, cepat, dan terjangkau lewat telepon genggam yang kita miliki.

Sejak kemunculannya, website adalah salah satu media sosial yang cukup eksis di masyarakat. Web merupakan ruang informasi dalam internet, yang menggunakan teks satu layanan yang dipakai oleh pemakai komputer yang terhubung ke internet (Betha Sidik, 2014). Hal ini pun dimanfaatkan oleh para pelaku media dan para penggerak dakwah untuk syiar dakwah Islam. Karena sifatnya yang tak mengenal ruang dan waktu dan cakupannya yang luas, website gemar dijadikan sebagai media dakwah Islam. AhmadSastra.com adalah salah satu website dakwah yang tergabung di media sosial saat ini.

Dakwah adalah ajakan dan seruan kepada jalan Allah yang dilakukan oleh seorang $d a{ }^{\prime} i$ (siapapun dia yang mengaku Muslim) kepada orang lain secara perorangan atau bersama-sama dengan tujuan merubah mad'u kepada keadaan yang lebih baik (Ali Abdul Halim, 1995). Seperti yang dijelaskan dalam firman Allah SWT dalam QS. Ali Imran: 104 yang Artinya: "Dan hendaklah di antara kamu ada segolongan orang yang menyeru kepada kebajikan, menyuruh (berbuat) yang makruf, dan mencegah dari yang mungkar. Dan mereka itulah orang-orang yang beruntung.". Dakwah adalah mengajak orang lain untuk meyakini dan mengamalkan akidah dan syariat Islam yang terlebih dahulu telah diyakini dan diamalkan oleh pendakwah itu sendiri (Abdullah, 2018). Website sebagai media dakwah tentunya harus mampu menyajikan pesan dakwah dengan penulisanyang baik sehingga mampu menarik perhatian pembaca (mad'u). Salah satu situs dakwah Islamyang konsisten menghadirkan artikel-artikel tentang isu keislaman, yang berisikan pesan-pesan dakwah adalah website AhmadSastra.com. AhmadSastra.com merupakan situs dakwah Islam baru yang muncul di media sosial saat ini. Ia berdiri pada November 2019 lalu dan konsisten eksis sampai 
sekarang. Sejauh perkembangannya, AhmadSastra.com merupakan salah satu situs Islam yang cukup terkenal dan familiar, khusunya di kalangan akademisi dan pemerintahan.

Berdasarkan data grafik yang peneliti dapatkan dari admin AhmadSastra.com, situs ini sudah dikunjungi oleh 10 negara diantaranya Indonesia dengan 24,508 kali penanyangan, Malaysia 2,388, Amerika Serikat 1,595, Israel 1,270, Uni Emirat Arab 942, Kanada 496, Singapura 205, Arab Saudi 76, Australia 63, dan 150 penanyangan dari wilayah yang tidak dikenal. Pada bulan Mei 2020 lalu, website ini sudah dikunjungi oleh 18.000 orang. Artinya artikel-artikel keIslaman yang ada dalam website ini, sudah di baca oleh lebih dari 10.000 orang setiap bulannya.

Dari sembilan rubrik yang ada di AhmadSastra.com, rubrik filsafat dan opini aktual adalah rubrik yang menarik perhatian pembaca. Oleh karena itu, penelitian ini berfokus pada rubrik tersebut. Di dalam rubrik tersebut, tersajikan tulisantulisan atau artikel keIslaman yang konsisten membahas tentang pemikiran Islam, isu-isu aktual tentang persoalan terkini, dan pesan-pesan dakwah yang berisikan tentang ajaran tauhid serta syariah yang menarik untuk didiskusikan. Berdasarkan hasil pengamatan awal peneliti, konten-konten dakwah yang terdapat pada rubrik ini dominan menggunakan bahasa yang keras, lugas, tegas, dan tak jarang cukup pedas.

\section{Pembahasan}

\section{a. Media Sosial}

Menurut Kamus Bahasa Indonesia, media adalah alat, sarana komunikasi, perantara, atau penghubung. Sedangkan sosial artinya berkenaan dengan masyarakat atau suka memperhatikan kepentingan umum (kbbi.id). Maka, dari sisi bahasa, media sosial dapat dimaknai sebagai sarana yang menghubungkan masyarakat untuk berkomunikasi dan berbagi.

Secara sederhana, istilah media biasa dijelaskan sebagai alat komunikasi (Nasrullah Rulli, 2016). Wikipedia.id mendefinisikan media sosial sebagai media daring, dengan para penggunanya bisa dengan mudah berpartisipasi, berbagi, dan menciptakan isi blog, jejaring sosial, wiki, forum, dan dunia virtual. Sedangkan menurut kamus Bahasa Inggris, media sosial merupakan program komputer yang memberikan fungsi untuk berkomunikasi dan berbagi informasi di internet.

Menurut Shirky dalam Nasrullah (2018), media sosial adalah alat untuk meningkatkan kemampuan pengguna untukberbagi (to share), bekerja sama (to cooperate) di antara pengguna dan melakukan tindakan secara kolektif yang semuanya berada di luar kerangka institusional maupun organisasi. Sedangkan menurut Van Dijk (2013), media sosial adalah platform media yang memfokuskan pada eksistensi pengguna yang memfasilitasi mereka dalam beraktivitas maupun berkolaborasi. Karena itu, media sosial dapat dilihat sebagai medium (fasilitator) online yang menguatkan hubungan antarpengguna sekaligus sebagai sebuah ikatan sosial.

Maka dapat disimpulkan bahwa media sosial adalah sebuah media yang memfasilitasi aktivitas kegiatan sosial duniawi yang bisa didapat saat jaringan internet terkoneksi yang di dalamnya, para pengguna bisa mendapatkan informasi- 
informasi dari berbagai belahan bumi. Media sosial menawarkan dunia baru, yang kebanyakan orangmenyebutnya sebagai "dunia dalam genggaman tangan".

\section{b. Website}

Abdullah Rohi (2015) mengartikan website sebagai sekumpulan halaman yang terdiri dari beberapa laman yang berisi informasi dalam bentuk data digital berupa text, gambar, video, audio, dan animasi lainnya yang disediakan melalui jalur koneksi internet. Bekti (2015), mendefinisikan website sebagai kumpulan halaman-halaman yang digunakan untuk menampilkan informasi teks, gambar diam atau gerak, animasi, suara, dan atau gabungan dari semuanya, baik yang bersifat statis maupun dinamis yang membentuk satu rangkaian bangunan yang saling terkait, yang masing-masing dihubungkan dengan jaringan-jaringan halaman.

Menurut Wikipedia.id, website adalah suatu halaman web yang saling berhubungan yang umurnya berada pada peladen yang sama berisikan kumpulan informasi yang disediakan secara perorangan, kelompok, atau organisasi. Peladen merupakan sistem komputer yang menyediakan jenis layanan tertentu dalam sebuah jaringan komputer. Maka dapat kita simpulkan bahawa website adalah salah satu jenis dari media massa (media sosial) yang berupa kumpulan dari beberapa halamanweb, di mana informasi tersebut disajikan dalam bentuk teks, gambar, suara, dan lain sebagaianya yang dipersentasikan dalam bentuk hypertext, dan dapat diakses oleh perangkat lunak yang disebut dengan browser.

\section{c. Definisi Dakwah}

Secara etimologi (bahasa) dakwah berasal dari bahasa Arab, yaitu da'a-yad'u - da'watan, yang mempunyai makna menyeru, memanggil, mengajak, dan melayani (Yunus Mahmud, 1965). Selain itu, juga bermakna mengundang, menuntun dan menghusung. Ini berarti bahwa apabila kata dakwah dimaknai atau diberi pengertian sebagai "seruan dan ajakan" maka yang dimaksudkan adalah seruan serta ajakan kepada Islam atau seruan Islam.

Orang yang berdakwah biasa disebut dengan $d a$ ' $i$ dan orang yang menerima dakwah atau orang yang didakwahi disebut dengan mad'u (Saputa Wahidin, 2011). Omar Yahya (2004) di dalambukunya "Islam dan Dakwah", menyatakan bahwa dakwah Islam adalah mengajak manusia dengan cara bijaksana kepada jalan yang benar sesuai dengan perintah Tuhan untuk keselamatan di dunia dan di akhirat. Ali Mahfuzh (2009) menyatakan bahwa dakwah adalah menyeru kepada kebajikan dan petunjuk serta menyuruh kepada kebajikan dan melarang kemungkaran agar mendapatkan kebahagiaan di dunia dan di akhirat. Hasjmy Ali, seorang ulama dari Aceh mengatakan bahwa dakwah adalah upaya mengajak orang lain untuk meyakini dan mengamalkan akidah dan syariat Islam yang terlebih dahulu telah diyakini dan diamalkan olehpendakwah itu sendiri.

Dakwah juga bisa diartikan sebagai proses penyampaian ajaran Islam kepada umat manusia. Sebagai suatu proses tentunya dakwah disini tidak hanya merupakan usaha penyampaian saja, tetapi merupakan usaha untuk mengubah way of thinking, way offeeling, dan way of life manusia sebagai sasaran dakwah ke arah kualitas kehidupan yang lebih baik (Amin, 2008). Jadi dapat disimpulkan bahwa dakwah adalah mengajak orang lain kepada Islam setelah orang yangmengajaknya 
itu menerapkan ajaran Islam ke dalam dirinya lebih dahulu. Dakwah menjadi aktivitas untuk menjalankan syariat Allah dan menjauhi larangan-Nya. Dakwah disampaikan dengan cara yang baik dan bijaksana. Hal ini seperti yang Allah uraikan dalam Al-Qur'an surat an-Nahl: 125 yang artinya, "Serulah (manusia) kepada jalan Tuhanmu dengan hikmah dan pelajaran yang baik dan bantahlah mereka dengan cara yang baik. Sesungguhnya Tuhanmu Dialah yang lebih mengetahui tentang siapa yang tersesat dari jalan-Nya dan Dialah yang lebih mengetahui orang- orang yang mendapat petunjuk".

\section{d. Tujuan dan Fungsi Dakwah}

Tujuan merupakan sesuatu yang ingin diwujudkan dan diterapkan. Tujuan terwujud melalui tindakan, perbuatan atau usaha nyata yang dilakukan. Tujuan dakwah berarti upaya untuk mewujudkan Islam sebagai rahmat bagi seluruh umat manusia. Menurut Aziz Ali (2004), di dalam bukunya Ilmu Dakwah, menuliskan bahwa tujuan pertama dakwah adalah untuk menghidupkan hati yang mati, agar manusia mendapat ampunan dan terhindar dari azab Allah, untuk menyembah Allah dan tidak menyekutukan-Nya, untuk menegakkan agama Allah dan mengajak serta menuntun manusia kepada jalan yang lurus.

Sementara itu Natsir dalam kutipan Ilmu Dakwah karya Aziz Ali, mengemukakan bahwa tujuan dari dakwah adalah: (1) untuk memangil kita pada syariat, memecahkan persoalan hidup, baik persoalan hidup perseorangan atau persoalan rumah tangga, masyarakat, bersuku dan bernegara; (2) bertujuan untuk memanggil kita pada fungsi hidup sebagai hamba Allah SWT, di atas dunia yang terbentang luas yang berisikan manusia secara heterogen, bermacam karakter dan pendirian serta kepercayaan; (3) untuk memanggil kita kepada tujuan hidup yang hakiki, yakni menyembah Allah SWT. "Dan aku tidak menciptakan jin dan manusia melainkan supaya mereka menyembah" (QS Ad- Dzariyat: 56).

Adapun fungsi dari dakwah yaitu untuk menyebarkan Islam kepada manusia sebagai individudan masyarakat sehingga mereka merasakan rahmat Islam sebagai rahmatan lil 'alamin bagi seluruh makhluk Allah SWT. Kedua, dakwah berfungsi melestarikan nilai-nilai Islam dari generasi ke generasi kaum muslimin sehingga kelangsungan ajaran Islam beserta pemeluknya dari generasi ke generasi berikutnya tidak terputus. Ketiga, dakwah berfungsi korektif artinya meluruskan akhlak yang bengkok, mencegah kemunkaran dan mengeluarkan manusia dari kegelapan, kekufuran, dan kemaksiatan.

\section{e. Pesan Dakwah Islam}

Pesan adalah sesuatu yang bisa disampaikan seseorang kepada orang lain, baik secara individumaupun kelompok yang dapat berupa buah pikiran, keterangan, dan pernyataan dari sebuah sikap (Tasmoro Toto, 1997). Maka pesan dakwah merupakan isi pesan atau materi dakwah yang disampaikan seorang $d a$ ' $i$ kepada mad'u. Pesandakwah berisikan tentang ajaran-ajaran Islam.

Astrid Susanto (1997) mengatakan bahwa pesan adalah ide, gagasan, informasi dan opini yang dilontarkan seorang komunikator kepada komunikan yang bertujuan untuk mempengaruhi komunikan ke arah sikap yang diinginkan oleh komunikator. Jadi, pesan dakwah adalah pesan-pesan keIslaman yang berisikan tentang ajaran-ajaran Islam yang sudah tentu berlandaskan pada ketetapan syariat 
(Al-Qur'andan Asu-Sunnah) serta sumber hukum Islam lainnya. Secara umum, pesan dakwah Islam adalah sebagai berikut:

\section{1). Pesan Akidah}

Akidah berasal dari bahasa Arab, yang bentuk jamaknya adalah a'qa 'id yang berarti kepercayaan atau keyakinan. Dalam Islambersifat $i$ 'tiqad bathiniyah yang mencakup masalah- masalah yang erat hubungannya dengan rukun iman. Akidah adalah pokok-pokok kepercayaan yang harus diyakini oleh setiap muslim berlandaskan nash danakal (Saputra Wahidin, 2011). Menurut istilah, akidah ialah iman yang kauat kepada Allah dan apa yang diwajibkan berupa tauhid (mengesakan Allah dalam peribadatan), beriman kepada malaikat-Nya, kitab-Nya, rasul-Nya, hari akhir dan takdir baik-buruk-Nya (Abdullah Abdul, 2007).

Akidah dalam Islam dijelaskan oleh Allah dalam dua rukun, yaitu rukun Islam dan rukun Iman "Iman ialah engkau percaya kepada Allah, Malaikat- malaikatNya, Kitab-kitab-Nya, Rasul-rasul-Nya, HariAkhir dan percaya adanya ketentuan Allah yang baik maupun yang buruk" (HR. Muslim).

Akidah menyangkut sistem keimanan atau kepercayaan terhadap Allah SWT. Dan ini menjadilandasan mendasar dalam keseluruhan aktivitasseorang muslim. Dalam Al-Qur'an, akidah disebutkan dengan istilah iman dan temannya, yakni syariah disebut dengan istilah amal sholeh. Keduanya memiliki korelasi yang tidak bisa dipisahkan. Artinya adalah keimanan dan kepercayaan harus diikuti oleh amal sholeh, karena iman tidaklah sempurna tanpa disertai oleh amal sholeh. Ketika kita sudah mengimani keenam rukun tersebut, maka selanjutnya adalah kita diminta untukmengaktualisasikan keimanan tersebut dengan amal sholeh atau tindakan yang nyata. Hal ini Allah jelaskan dalam rukun Islam yaitu kita harus mengucapkan dua kalimat syahadat, mendirikan shalat, menjalankan puasa, menuanaikan zakat, dan pergi haji bila mampu. Jika kelima hal ini, sudah kita jalankan, maka sebutan kita berganti menjadi seorang muslim (orang yang berislam).

\section{2). Pesan Syariah}

Syariah secara bahasa adalah peraturan atau undang-undang. Pesan syariah berarti pesan-pesan yang di dalamnya mencakup tata aturan ajaran Islam atau yang sering kita sebut sebagai syariat Islam. Pesan syariah merupakan pesan mengenai tingkah lakuyang mengikat yang harus dipatuhi dan dilaksanakan sebagaimana mestinya (Mujieb Abdul, 1994).

Syariat yaitu serangkaian ajaran yang menyangkut aktivitas manusia muslim di dalam semuaaspek hidup dan kehidupannya, mana yang boleh dilakukan, dan yang tidak boleh, mana yang halal dan haram, mana yang mubah dan sebagainya. Dan ini juga menyangkut hubungan manusia dengan Allah danhubungan manusia dengan sesamanya (hablun minallah dan hablun minan nas). Pesan syariah terbagi menjadi dua yaituibadah dan muamalah. Peraturan-peraturan ibadah seperti sholat, puasa, zakat, naik haji dan lain-lainnya adalah contoh dari pesan syariah ibadah yang konteksnya langsung terhubung kepada Allah (hablun minallah). Sedangkan muamalah adalah pesan Syariah yang konteksnya dengan sesama manusia (hablu minannas) seperti perkara jual-beli (hukum niaga), pernikahan, hukum waris, pidana, hukum negara dan lain sebagainya. 


\section{3). Pesan Akhlak}

Secara etimologi akhlak berarti budi pekerti, peringai, perilaku, atau tabiat. Menurut Anis Ibrahim (1972) akhlak adalah sifat yang tertanam dalam jiwa, yang dengannya lahirlah perbuatan-perbuatan, baik atau buruknya tampa membutuhkan pemikiran atau pertimbangan. Menurut Shaleh Hasan, (2000:56), akhlak adalah sesuatu perilaku yang menggambarkan seseorang yang terdapat dalam jiwayang baik, yang darinya keluar perbuatan yang mudah dan otomatis tanpa berfikir sebelumnya.

Manusia dan akhlak adalah dua hal yang tidak bisa dipisahkan. Di dalam kehidupan ini, kita mengenal sebutan akhlak baik dan akhlak buruk, manusia baik dan manusia jahat, terpuji dan tercela, baik dan buruk, dan lain sebagainya. Kedua nilai tersebut menjadi satu paket yang sudah di desain dengan begitu apik oleh sang pencipta. Dalam hal ini. akhlak menjadi aturan nilai-nilai yang mengatur sikap dan tingkah laku manusia di dalam kehidupannya. Pesan akhlak di dalam dakwah Islam sudah tentu adalah pokok-pokok nilai dan aturan yang baik baik kehidupan manusia. Karena ajaran Islam merupakan ajaran yang sempuran, tanpa cela, dan membuat manusia menjadi manusia yang karimah. Akhlak timbul dari maifestasi pengetahuan, pengalaman, pelajaran hidup, dan hikmah yangdidapat oleh setiap manusia. Kita sering berpandangan bahwa di bumi ini, sedikit sekali manusia yang berakhlak baik.

Hal tersebut disebabkan karena manusia memiliki kekurangan jiwa yang tidak disadarinya (sebab akhlak adalah nilai yang begitu saja timbul). Sifat-sifat ini pun sudah Allah jelaskan di dalam Al-Qur'an, bahwasanya manusia memiliki sifat yang buruk dan jahil, diantaranya adalah mudah berputus asa, zalim, suka berkeluh kesah, kikir, suka membantah, melampaui batas, tidak disiplin, berbuat dosa, suka berburuk sangka, lemah, dan lain sebagainya (Suhandang Kustadi, 2013). Oleh karena itu, Islam hadir untuk meminimalisir akhlak-akhlak tersebut. Allah pun mengutus Rasulullah untuk menyempurnakan akhlak manusia dan membawa serta ajaran Islam. "Aku (Muhamamd) diutus oleh Allah di dunia ini hanyalahuntuk menyempurnakan akhlak" (HR. Ahmad).

\section{f. Website Sebagai Media Dakwah}

Islam adalah agama dakwah. Yaitu agamayang menegaskan ummatnya untuk menyebarkan dan menyiarkan Islam kepada seluruh umat manusia di bumi ini. Seiring waktu berjalan, perkembangan zaman semakin canggih, dan teknologi pun kian mutakhir. Website menjadi salah satu media yang masih eksis sejak pertama kali muncul di permukaan media sosial (internet). Berawal dari sekedar penghubung komunikasi antar jaringan pada sebuah jaringan militer, website pun kini kian berkembang.

Dewasa ini, website dijadikan sebagai wadah untuk syiar Islam. Sudah banyak kita temukan situs-situs dakwah Islam yang tersebar di beranda media sosial kita. Mereka muncul dengan sangat beragam. Ada yang berdiri atas tekad perorangan, berdiri bersama naungan lembaganya, juga, ada yang berdiri bersama dengan portal-portal berita regional dan nasional. Hal tersebut, membuktikan bahwa website menjadi sarana yang cukup efektif untuk menyebarkan informasi, terkhusus informasi terkait syiar-syiar keislaman. 
Salah satu fungsi media sosial adalah untuk membentuk masyarakat dengan budaya yang baik. Dan Islam adalah agama yang berisikan tentang budaya-budaya baik. Agar fungsi tersebut dapat teraktualisasikan dengan tepat, maka sudah sepatutnya setiap muslim melek akan perkembangan digital ini. Website bisa menjadi lahan luas untuk berdakwah. Dengannya, kita bisa memperkenalkan dakwah Islam kepada masyarakat banyak, mengingatkan mereka yang muslim untuk senantiasa menjalankan syariat Islam, menebarkan kisah-kisah keindahan Islam, dan menjadi kontrol sosial atas stigma negatif kaum orientalis terhadap umat Islam.

Dengan adanya website pun, pesan dakwahdan informasi Islam yang ditulis dapat dibaca oleh ratusan, ribuan, bahkan jutaan mad'u tanpa ada batasan waktu. Hal ini jelas membuat dakwah melalui website, menjadi media yang cukup efektif untuk berdakwah. Tak hanya itu, website juga dapat menjadi media untuk memengaruhi orang secarakuat dan massif.

Website bisa menjadi alat untuk membentuk sebuah pemahaman atau ideologi. Pada dasarnya, semua media sosial yang ada pun sudah tentu berusaha untuk mendakwahkan sebuah ide dan pemahaman kepada masyarakat. Media memang memiliki kemampuan yang besar dalam menyebarkan pesan-pesan kepada banyak orang. Oleh karena itu, website menjadi media yang cukuprelevan bagi penyebaran dakwah Islam.

\section{g. Analisis Konten}

Menurut yang tercantum dalam Kamus Besar Bahasa Indonesia (2002), analisis adalah penguraian suatu pokok atas berbagai bagiannya dan penelaahan bagian itu sendiri serta hubungan antar bagian untuk memperoleh pengertian yang tepat dan pemahaman dari arti keseluruhan. Atau penyelidikan terhadap suatu peristiwa (karangan, perbuatan, dan sebagainya) untuk mengetahui keadaan yang sebenarnya (sebab-musabab, duduk perkaranya, dan sebagainya).

Analisis adalah sebuah kegiatan untuk mencari suatu pola. Selain itu analisis juga merupakan cara berpikir yang berkaitan dengan pengujian secara sistematis terhadap sesuatu untuk menentukan bagian, hubungan antar bagian dan hubungannya dengan keseluruhan (Sugiyono, 2015). Analisis isi dimaksudkan sebagai usaha untuk mengurai suatu masalah atau fokus kajian menjadi bagianbagian (decomposition) sehingga susunan atau tatanan bentuk sesuatu yang diurai itu tampak dengan jelas dan karenanya bisa secara lebih terang ditangkap maknanya atau lebih jernih dimengerti duduk perkaranya (Satori \& Komariyah, 2014).

Sedangkan makna isi menurut Kamus Besar Bahasa Indonesia adalah sesuatu yang ada (termuat,terkandung, dan sebagainya) di dalam suatu benda atau inti serta bagian yang pokok dalam suatu pembicaraan; apa yang tertulis di dalamnya (buku, surat, dan sebagainya) (kbbi.web.id). Maka analisis isi (content analysis) adalah penelitian yang bersifatpembahasanmendalam terhadap isi suatu informasi tertulis atau tercetak di dalam media massa. Harold D. Lasswell menjadi pelopor dari analisis ini. Ia membuat teknik symbol coding yaitu berupa pencatatan terhadap pesan atau lambang secara sistematis untuk kemudian dapat diinterpretasikan oleh peneliti (Setiawan \& Muntaha, 2004). Di dalam ilmu komunikasi, analisis isi 
menjadi metode ilmiah untuk memperlajari dan menarik kesimpulan atas suatu fenomena (peristiwa) dengan memanfaatkandokumen (teks).

Penelitian-penelitian yang mempelajari isi media (surat kabar, radio, film, televisi, dan sosial media), biasanya menggunakan analisi isi. Lewat analisis isi, peneliti dapat mempelajari gambaranisi, karakteristik pesan, dan perkembangan (trend) dari suatu isi (Eriyanto, 2011). Holsti (1969) menambahkan bahwa analisis isi ini adalah suatu teknik untuk mengambilkesimpulan dengan mengidentifikasi berbagai karakteristik-karakteristik khusus suatu pesan secara objektif dan sistematis. Objektif berarti menurut aturan atau prosedur yang apabiladilaksanakan oleh orang (peneliti) lain dapat menghasilkan kesimpulan yang serupa. Sistematis artinya penetapan isi atau kategori dilakukan menurut aturan yang diterapkan secara konsisten, meliputi penjaminan seleksi dan pengkodingan data agar tidak bias.

Maka, dapat kita simpulkan bahwa analisis isi digunakan untuk menganalisis semua bentuk komunikasi, baik surat kabar, berita radio, iklan televisi maupun semua bahan-bahan dokumentasi yang lain sekaligus media sosial (internet). Analisis isi menjadi salah satu metodelogi penelitian yang bersifat mendalam terhadap informasi tertulis atau tercetak pada suatu media massa. Karena pada analisis ini, peneliti mendalami tentang teks dansumber-sumber data terkait. Dan data analisis yang digunakan pada penelitian ini adalah materi (pesan) dakwah yang tertuang dalam website AhmadSastra.com.

\section{h. Analisis Wacana Van Dijk}

Pengertian analisis wacana terdiri dari dua kata, yaitu analisis dan wacana. Analisis menurut Kamus Besar Bahasa Indonesia (KBBI) adalah penyelidikan terhadap suatu peristiwa, penjelasan sesudah dikaji sebaik-baiknya, penguraian suatu pokok atas berbagai bagian, serta penguraian karya sastra atau unsurunsurnya untuk memahami pertalian atas unsur tersebut (KBBI, 1988).

Secara etimologi istilah wacana berasal dari bahasa Sansekerta wac/wak/uak yang memiliki arti 'berkata' atau 'berucap'. Kemudian kata tersebut mengalami perubahan menjadi wacana. Kata 'ana' yang berada di belakang adalah bentuk sufiks (akhiran) yang bermakna 'membendakan' (nominalisasi). Dengan demikian, kata wacana dapat dikatakan sebagai perkataan atau tuturan (Mulyana Dedi, 2005). Dalam Kamus Bahasa Indonesia Kontemporer (Salim Peter, 2002) terdapat tiga makna dari istilah wacana. Pertama, percakapan, ucapan dan tutur. Kedua, keseluruhan tutur atau cakapan yang merupakan satu kesatuan. Ketiga, satuan bahasa terbesar, terlengkap yang realisasinya pada bantuk karangan yang utuh, seperti novel, buku dan artikel.

Wacana adalah rentetan kalimat yang berkaitan, yang menghubungkan proposisi yang satu dengan proposisi lainnya, membentuk satu kesatuan sehingga terbentuklah makna yang serasi diantara kalimat-kalimat itu; kesatuan bahasa yang terlengkapdan tertinggi atau terbesar di atas kalimat atau klausa dengan koherensi (kepaduan wacana sehingga membawa ide tertentu yang dipahami oleh khalayak) dan kohesi (keserasian hubungan unsur-unsur) yang tinggi yang 
berkesinambungan, yang mampu mempunyai awal dan akhir yang nyata, dan disampaikan secara lisan atau tertulis (Eriyanto, 2018).

Dalam buku "Analisis Wacana; Pengantar Analisis Teks Media" karangan Eriyanto (2018), di dalamnya berisikan tentang teori-teori terkaitanalisis wacana yang diperkenalkan dan dikembangkan oleh para ahli. Para ahli tersebut, diantaranya ada Roger Fowler, dkk (1979) tentang critical linguistik (bahasa sebagai praktik sosial), Theo Van Leeuwen (1986) yakni memperkenalkan analisis untuk mendeteksi dan meneliti tentang kaum marjinal. Sara Mills (1992) yang membahas pada perspektif feminisme, dan Norman Fairclough (1978) yaitu mengenai wacana tentang suatu ideologi. Dan dari banyaknya tokoh yang mengembangkan analisis wacana tersebut, model Teun Van Dijk lah yang sering dipakai dalam berbagai penelitian teks media. Hal ini kemungkinan karena Van Dijk mengelaborasi elemen-elemen wacana sehingga bisa didayagunakan dan dipakai secara praktis. Model yang dipakai oleh Van Dijk ini sering disebut sebagai "kognisi sosial". Menurutnya, penelitian tidak cukup jika hanya didasarkan pada analisis atas teks semata, karena teks hanya hasil dari suatu praktik produksi yang harus juga diamati.

Analisis wacana pada model ini, digambarkan mempunyai tiga demensi, yaitu teks, kognisi sosial dan konteks sosial. Inti analisis Van Dijk adalah menggabungkan ketiga analisis tersebut dalam satu kesatuan analisis. Dalam dimensi teks, yang diteliti adalah bagaimana struktur teks dan strategi wacana yang dipakai untuk menegaskan suatu tema tertentu. Pada level kognisi sosial dipelajari proses produksi teks berita yang melibatkan kognisi individu penulis. Sementara itu aspek konteks sosial mempelajari bangunan wacana yang berkembang dalam masyarakat mengenai suatu masalah (Eriyanto, 2018).

\section{Hasil dan Pembahasan}

\section{a. Analisis Peneliti terkait Latar BelakangWebsite}

Sebelumnya, peneliti ingin mendeksripsikan definisi tentang artikel terlebih dahulu. Artikel adalah tulisan lepas berisi opini seseorang yang mengupas tuntas suatu masalah tertentu yang sifatnya aktual atau kontroversial dengan tujuan untuk memberitahu (informatif), memengaruhi, dan meyakinkan (persuasif argumentatif), atau menghibur khalayak pembaca (rekreatif). Lepas berarti, setiap orang boleh menulis artikel sesuai dengan kemampuannya dan dibolehkan untuk dituju kepada siapa pun atau apapun. Artikel ini biasanya dituliskan oleh para kaum pemikir dan intelektual yang bertujuan untuk membagikan informasi atau peristiwa yang didapat, dirasa, dan dialaminya.

Sedangkan secara pengertian jurnalistik, artikel merupakan bagian dari produk jurnalistik views (opini). Artikel biasa terdapat pada surat kabar dan majalah. Saat ini, akibat perkembangan zaman yang semakin canggih, media merambah maju ke media sosial (online). Para pelaku media pun ikut memanfaatkan sosial media sebagai alat penyebaran berita dan artikel-artikelnya. Salah satu media sosial yang menjadi pilihan adalah website, situs, dan atau portal berita.

Tak hanya media lama yang bermetamorfosa, kini, media-media baru pun ikut bermunculan menghiasi layar mini ponsel pintar kita.AhmadSastra.com adalah salah satu media yang ikut muncul dalam beranda media sosial website saat ini. 
AhmadSastra.com didirikan pada 02 Desember 2019 lalu oleh Ahmad Sastra. Ahmad Sastra adalah seorang pakar pemikiran dan filsafat. Ia seorang dosen dari Mahasiswa Pasca Sarjana Universitas Ibn Khaldun Bogor.

Ahmad Sastra merupakan sosok yang aktif dalam dunia kepenulisan dan literasi. Artikel-artikelnya pun cukup banyak bersliweran di media massa. "Saya sudah biasa menulis. Mungkin sudah ratusan dan sudah dimuat di website orang, ada yang izin dan tidak izin. Tulisan saya itu tercecer di banyak tempat", ungkapnya saat diwawancarai olehpeneliti pada Maret 2020 lalu. "Oleh karena itu, ada keinginan juga untuk membuat website sendiri walaupun awalnya saya tidak bisa membuatnya seperti apa. Sampai ada orang yang menawarkan jasa pembuatan". ungkapnya lagi.

Ahmad Sastra memang cukup aktif dalam dunia kepenulisan dan literasi. Tak jarang, banyak pimpinan media yang melirik artikel-artikelnya tersebut untuk dipublish ke dalam media miliknya. Jika kita mencari lewat mesin pencarian (google), dengan mengetik Ahmad Sastra saja, kita bisa mendapatkan artikelartikelnya yang sudah dimuat oleh cukup banyak media baik online maupun cetak. Tak hanya aktif dalam dunia literasi, Ahmad Sastra juga giat dalam menggencarkan dakwah Islam. Ia menjadikan keaktifannya dalam menulis sebagai metode dakwahnya.

Belakangan peneliti ketahui bahwa ia juga seorang kolumnis (penulis kolom atau artikel) di salah satu media massa bergengsi di Indonesia. Maka sudah tersematkan bahwa jati dirinya adalah seorang yang aktif dalam dunia syiar, baik sebagai dosen, pemikir, penulis, jurnalis atau kolumnis, dan da'i."Awalnya website ini hanya sebagai media untuk dokumentasi tulisan saya dan media dakwah saya untuk menyebarkan Islam dengan jangkauan yanglebih luas", urainya kepada peneliti.

"Ke sini, saya tertarik untuk menjadikan website ini sebagai media yang bisa berjalan bersama media lainnya. Karena harapan saya sederhana, saya hanya ingin, saya ini bisa menjadi pencerah bagi pemikiran dan kesadaran umat untuk lebih baik, umat menjadi lebih tercerahkan dan kemudian saya berharap bisa makin produktif, kontributif, dan memberi manfaat bagi banyak orang". jelasnya saat di tanya alasan mendirikan website ini oleh peneliti.

Berdasarkan latar belakang tersebut, peneliti mengamati sejak 6 bulan terakhir ini, Ahmad Sastra memang aktif dalam menulis artikel dan diposting ke dalam websitenya. Terlihat dari data statistik pengunjung, setiap bulannya website ini terus meningkat (data ada pada halaman lampiran). Peneliti menganggap bahwa hal ini menjadi nilai penting karena website ini dapat dilirik oleh masyarakat. Ke depannya Ahmad Sastra sedang mempersiapkan perizinan terkait keinginannya untuk membuat media yang lebih profesional. Hal ini, sudah ia pikirkan dan sedang ia persiapkan segala perizinan untuk mendirikan perusahan medianya.

\section{Analisis Konten Dakwah PadaAhmadSastra.com}

Fokus penelitian peneliti adalah artikel pada rubrik Opini Aktual AhmadSastra.com. Dan karena banyaknya, artikel yang termuat di sana, peneliti mengambil tiga artikel yang peneliti nilai memiliki korelasi di antra ketiganya. Adapun pesan dakwah yang terkandung dalam tiga judul yang telat peneliti teliti 
adalah sebagaimana di bawah ini. Namun, sebelum itu peneliti ingin mendeskripsikan hasil analisis peneliti tentang ketiga judul penelitian: (Teks 1: Narasi Islam Radikal) Radikalisme berasal dari bahasa Latin yang bermakna akar. Sedangkan Isme adalah suatu paham, pandangan, atau paradigma. Artinya Radikalisme adalah suatu pemahaman yang mendalam, mengakar, dan mendasar. Dalam kaidah ilmu filsafat, radikalismesering di sebut-sebut sebagai penetrasi dari pemikiran yang mendalam. Sependek pengetahuan peneliti dalam memaknai radikal dalam Islam artinya pemahaman tentang Islam sampai ke pada akarnya. Artinya seorang muslim benar-benar memahami Islam secara keseluruhan dan mendasar. Dalam kajian ilmu filsafat Islam, radikal adalah kata yang biasa, sebab termasuk pada salah satu wujud kesifatan manusia untuk mendalami agamanya secara utuh dan mendasar. Hal demikian, dimaknai agar muslim dalam menjalani kehidupannya akan senantiasa berpegang teguh pada ajaran Islam yang utuh, tidak akan mudah di propaganda dan tidak akan mudah untuk berpindah haluan. (Data ini peneliti dapatkan dari kajian dan materi perkuliahan Filsafat Islam).

Yang menjadi polemik saat ini adalah propaganda yang diluncurkan oleh oknum Barat untuk memporak-porandakan Islam dan umatnya. Maka narasi radikal yang biasa saja ini berubah 360derajat maknanya menjadi arti yang sangat ektream. Narasi radikal digiring menjadi suatu paham baru yang saat ini diubah maknanya oleh oknum pembenci Islam. Sependek pengetahuan peneliti, awalnya makna radikal ini tidak terlalu menyeramkan,namun semakin ke sini istilah radikal ini digiring untuk mengatakan bahwa muslim yang taat adalah muslim yang radikal. Radikal ini bisa membahayakan umat bernegara di Indonesia. Peneliti tidak akan mengkaji lebih dalam tentang hal ini, karena peneliti menyadari kemampuan peneliti yang masih sedikit. Peneliti hanya membuka deksripsi teks analisis pada tema 1 ini dengan menguraikan pelajaran dan pengalaman yang peneliti dapatkan tentang radikal danradikalisme selama di bangku perkuliahan.

Mengenai artikel "Narasi Islam Radikal" yang ditulis oleh Ahmad Sastra ini penulis mendapatkan hasil penelitian yang beragam. Sebagian besar informan yang peneliti wawancarai, sepakat dengan apa yang dituliskan oleh Ahmad Sastra tentang istilah radikalisme yang dijadikan perang istilah untuk memecah belah umat Islam.

\footnotetext{
"Monsterisasi ajaran Islam melalui perang istilah (harb al Musthalahat) sebagai radikal, garis keras (hard line) dan membenturkan dengan Islam moderat adalah proyek barat untuk memecah belah umat Islam sekaligus melumpuhkan kebangkitan umat" (paragraf 1)
}

Berdasarkan paragraf di atas, Ahmad Sastra menghimbau kepada kaum muslim agar tidakterkontaminasi dengan perang istilah yang digencarkan oknum Barat ini. Kemudian dilanjutkan dengan teks, "biasanya Barat akan menjadikan kaum munafik sebagai patner untuk membantu proyeknya".

\footnotetext{
"Dalam perang istilah ini, barat akan terus mereduksi dan mendistorsi ajaran Islam dengan tujuan westernisasi. Targetnya adalah umat Islam akan kehilangan ilmu dan tsaqafahnya. Maka, lahirlah muslim yang otaknya liberal yang justru berusaha meruntuhkan bangunan pemikiran Islam”. Untuk memahamkan umat agar tidak terpecah, para pemikir Islam, termasuk Ahmad Sastra jadi sepakat menyebut bahwa Islam adalah Islam. Islam adalah agama yang kaffah dan sempurna.

"Maka, istilah garis keras atau garis loyo, radikal atau moderat, liberal atau
} 
fundamentalisadalah istilah-istilah barat yang harus ditolak oleh kaum muslimin. Umat Islam harus terus waspada dan peka ketika menjumpai istilah-istilah asing dan berusaha perpegang teguh atas istilah-istilah syar'i sebagaimana telah Allah tetapkan".

Pada teks 1 ini peneliti menganalisis bahwa apa yang dituliskan oleh Ahmad Sastra memang apa adanya dan hal ini terjadi. Ia juga memutar kilasbalik sejarah dakwah Rasulullah yang selaludihalang-halangi dan dimusuhi kafir dan munafik karena dakwahnya. Pada teks 1 ini, Ahmad Sastra menginformasikan kepada umat Islam agar jangan gentar dan teruslah berjuang. Meskipun pada kenyataannya, yang banyak terpapar narasi Islam radikal ini adalah para kaum intelektual dan cendekiawan muslim Indonesia.

\begin{abstract}
"Umat Islam harus terus waspada terhadap racun istilah yang ditebarkan di media massa oleh Barat dan antek-anteknya. Khusu ulama dan kaum intelektual muslim yang paham, hendaknyamelakukan gerakan jihad membongkar agenda Baratdan antek-anteknya melalui perang istilah ini. Maka, janganlah pernah berhenti dalam memperjuangkan Islam, meskipun kaum kafir dan munafik akan terus menghadangnya dengan berbagai cara, dari yangpaling halus hingga yang paling brutal. Teruslah melangkah maju sebagai pejuang Islam sampai mati,jangan pernah menjadi pecundang dan pengecut. Islam adalah kebenaran. Kekafiran dan kemunafikanadalah kesesatan".
\end{abstract}

Dalam teks 2 yang berjudul "Hijrah, Radikal, Teroris, Bendera Hitam, Pancasila, Al-Qur'an, Soekarno, dan Nabi Muhammad" adalah bentukopini terkait isu yang viral pada November 2019 lalu. Dalam artikel ini, Ahmad Sastra sengaja menuliskannya untuk Sukmawati karena video viralnya yang telah membandingkan Rasulullahdengan Ayahnya, Soekarno. Ahmad Sastramengecam keras tindakannya karena dianggap telah melukai hati umat Islam dan telah melecehkan Islam. Ia menguraikan dengan sangat jelas kontroversi-kontroversi yang dilakukan oleh Sukmawati. Pada akhir artikelnya, ia menitipkan pesan syariah kepada pihak berwenang agarkontroversi Sukmawati ini diproses hukum dandiberikan hukum yang sesuai agar menjadi efek jeradan tidak ada lagi Sukmawati lainnya. "Semogapenegak hukum segera bisa memproses hukum atas pelecehan agama yang dilakukan oleh Sukmawati.Jika hal ini dibiarkan, maka berbagai pelecehanyang lebih parah akan terus terjadi. Tunjukkan bahwa negara ini berdasarkan hukum, tunjukkan!" Pada teks ketiga yang berjudul "Demokrasi Sekuler Makin Menyuburkan dan Melindungi Para Penista Agama". Pada bagian teks ini banyak pesan- pesan yang disematkan oleh Ahmad Sastra, yang dianggap sebagai ideologinya oleh para pembaca dan responden peneliti. Pada artikelnya itu, Ahmad Sastra menguraikan bagaimana Indonesia sebagai negara yang menggunakan sistem demokrasi sekuler yang anti pada formalisasi syariah. "Indonesia sendiri adalah negara demokrasi sekuler yang anti formalisasi syariah. Berbagai upaya dan perjuangan umat untuk mengembalikan Islam dalam ranah negara dianggap sebagai tindakan radikal danfundamentalis yang layak dimusuhi. Sementara tindakan yang justru melecehkan agama layak dilindungi dan disuburkan".

Dan dikuatkan oleh kalimat selanjutnya yaitu, "Visi demokrasi sekuler adalah memisahkan agamadari negara. Suara-suara sumbang yang meragukan peran agama dalam negaraditumbuhsuburkan dalam rangka mencapai visi sekulerisme. Memisahkan agama dari negara dan menistakan ajaran agama adalah bentuk 
radikalisme sekuler yang mendapat angin segar dari Barat". "Maka jangan heran jika dengan menerapkan demokrasi sekuler liberal sama artinya sedang menyuburkan lahirnya para penista agama, terutama Islam. Sebab demokrasi sendiri adalahideologi anti Islam. Demokrasi adalah ideologi, bukan alat, maka harus dilenyapkan dan ditegakkan Islam. Sebagaimana Rasulullah menumbangkan ideologi jahiliyah dan menegakkan daulah Madinah".

Menurut peneliti, pada artikel ini Ahmad Sastra terlalu detil tentang penjelasan demokrasisekuler dan Khilafah Islam. Peneliti mendapatkan bahwa dalam artikel ini, Ahmad Sastra lupa menyematkan contoh-contoh kejadian apa yang membuat demokrasi sekuler melindungi para penista agama. Jika penulis kaitkan dengan artikel sebelumnya, tentu hal ini memiliki korelasi. Pada teks ini pun, terjadi pro kontra antar responden narasumber. Muhammad Kamal Ihsan (Hangka) menuturkan pendaptnya, "Tulisan ini cerdas, berbobot, dan tulisan ini tulisan yang ambisius. Tulisan ini mempunyai ketajaman dalam argumentasi dan cerdas dan mampu secara tajam memasukkan ideologi atau pemahaman dalam sebuah kalimat yang terstruktur secara rapih.", saatditanya peneliti terkait penulisan pada artikel Ahmad Sastra.

"Penyampaian dan juga ambisi untuk menghidupkan yang namanya ideologi, yakni tentang harus ditegakkan negara yang harus berdasarkan perundangundangan Islam. Dalam konteks ini, masih bisa untuk diperdebatkan dan didiskusikan". ungkapnya dalam merespon artikel ini. Kamal Ihsan pun menuturkan lagi bahwa pembahasan tentang demokrasi dan sistem Islam yang harus diterapkan di Indonesia adalah hal yang sensitif untuk disebarkan pada media luas ini. Karena hal ini, masih bisa didiskusikan dan memang perlu untuk didiskusikan.

Harun Selano, seorang aktifis dakwah menuturkan, "Pancasila itu sifatnya elastis dia bisa ditarik kemanasaja itu cocok bagi pemeluk-pemelukagama yang ada diindonesia ini, jadi ketika kita meletakkan indonesia ini berasaskan islam berideologikan islam maka secara tidak langsung kita telah mendiskriminasi saudaa-saudara kita yang beragama lain sebenarnya, nah justru dengan adanya nilai pancasila itulah yang menjadi perekat dari semua yang ada dari segala kepercayaan yangada itu".

Ghita, Mahasiswi yang aktif dalam dunia dakwah, memberikan komentar keras terhadap artikel ini. "Dakwah itu mengajarkan cinta bukan kebencian, apalagi untuk kepentingan pribadi atau organisasi. Sekalipun isinya fiqih, saya yakin website ini akan tetap menjerumuskan orang-orang yang membacanya kepada pikiran-pikiran radikal, untuk merusak tatanan kehidupan bernegara". Namun berbeda dengan Tri Wulandari yang juga aktivis dakwah kampus. Tri mengatakan bahwa Islam adalah jawaban dari segala perkara kehidupan dan ia sangat menerima baik pesan dakwah pada website ini. "Sangat-sangat diterima karena sangat logika banget karena di samping penulis mampu memaparkan fakta, lalu memaparkan penyebabnya seperti apa, setelah itu memaparkan akibatnya yang terjadi karena melakukan sebab-sebab tadi dan ujungnya adalah solusi. Nah, penulis tidak hanya mengkritisi tapi sampai pada solusi dan solusinyatidak lain adalah Islam".

"Untuk informasi konten dakwah dapat diterima dengan baik, dan merupakan 
bacaan untuk muslim tingkat lanjut yang sudah yakin Islam sebagai jalan hidupnya dan bacaan ini menjadi penguatnya, karena tulisan lebih banyak mengupas dari sudut pandang Islam. Banyak informasi baru yang saya terima dan banyaknya istilah asing dalam konten menjadikan wawasan bertambah. Namun, ketika membaca agak terganggu dengan penggunaan kata yang meruncing ke pihak lain, dan jika tak terbiasa membaca konten serupa mungkin akan beranggapan tulisan web ini sangat tendensius", ujar Anisah Maryam, dari Pemuda Dewan Dakwah Islamiyyah Indonesia.

Saat dikonfirmasi oleh peneliti terkait kontendakwahnya yang tak biasa ini, Ahmad Sastra menerima segala kritik dan masukan yang datang. "Saya membuka ruang interpretasi. Membuka ruang kepada orang lain untuk memberika tanggapan dan menilai. Karya itu harus terbuka untuk orang lain. Bahwa jika orang lain menilai bahwa tulisan saya adalah tegas, lugas, dan pedas itu kan penilaian orang lain". tutur Ahmad Sastra kepada peneliti. Ia juga menambahkan, "Saya secara pribadi, bahwa kebenaran itu harus disampaikan, meluruskan yang bengkok, mencerahkan yang gelap, problem-problem kemasyarakatan harus kita lihat, harus kita analisa dan harus kita berikan solusi karena Islam itu kan harus tegas karena Islam mengajarkan kita harus memberikan solusi dengan tegas tapi kan tidak memaksakan karena ini berbentuk tulisan".

"Tapi yang hak adalah hak, yang batil adalah batil ini harus disampaikan. Misalnya pelacuran itu haram, minuman keras haram, nasionalisme haram. Nah nasionalisme ini haram, ini kan nanti akan berbenturan dengan ide-ide orang lain. Bahkan ada muslim yang mengatakan bahwa nasionalisme itu tidak haram, ya tidak jadi masalah, kan nanti ada diskusi dan yang penting berargumen. Kalau saya mengatakan nasionalisme itu haram kemudian dianggap keras, ini kan hanya sebuah pemahaman umum masyarakat Indonesia yang bahkan seorang muslim itu mengatakan nasionalisme itu tidak haram kan berarti ini hanya perbedaan sudut pandang dan argumen dan ini adalah hal yang biasa", tutup Ahmad Sastra atas penilaian pembacanya.

\section{Keterangan:}

\section{Pesan Dakwah pada Teks 1 "Narasi Islam Radikal"}

Dari keseluruhan tulisan yang terdapat pada teks 1, yang berjudul "Narasi Islam Radikal" dapat diambil kesimpulan bahwa pesan dakwah yang terkandung di dalamnya adalah pesan aqidah. Karena berkaitan erat dengan hal ketauhidan dan keesaan Tuhan. Pesan akidah karena berkaitan erat dengan hal ketauhidan dan keesaan Tuhan. Pesan syariah dikuatkan oleh penulisdengan dalil "Kamu adalah umat yang terbaik yangdilahirkan untuk manusia, menyuruh kepada yang ma'ruf, dan mencegah dari yang munkar, dan beriman kepada Allah". (QS Ali Imran: 110). Daliltersebut mengartikan bahwa Ahmad Sastra mengajak kepada seluruh kaum muslim untuk selalu menjalankan amar makruf dan nahi munkar.

Pesan Dakwah pada Teks 2 'Hijrah, Radikal, Teroris, Bendera Hitam, Pancasila, Al-Qur'an, Soekarno, dan Nabi Muhammad"

Pesan dakwah yang terkandung di dalamnyaadalah pesan aqidah, syariah, dan akhlak. Pesan akidah tersematkan pada makna hijrah, Al-Qur'an, dan Rasulullah yang tidak bisa ditawar-tawar untuk tidak diyakini atau dan diragukan. Dalam Al-Qur'an, sudah jelas bahwa Islam menyuruh umat muslim untuk beriman yang diantaranya adalah beriman kepada Rasul Allah dan Kitab-kitab Allah. Serta menjalankan syariatnya dengan takwa artinya denganmenjalani segala perintah-Nya dan menjauhi segala larangan-Nya.

Pesan syariah tersemat pada kalimat akhir Ahmad Sastra untuk para penegak hukum agar mengadili Sukmawati dengan seadil-adilnya, hukum pidana diterapkan agar tidak ada lagi SukmawatiSukmawati lainnya yang bisa dengan mudah melontarkan kalimat-kalimat yang bermakna 
ketauhidan. Pesan Akhlak digambarkan Ahmad Sastra pada uraian tentang kontroversi yang dilakukan oleh Sukmawati adalah ngawur alias gagal paham. Artinya, Sukmawati diminta untuk belajar lagi tentang Islam agar mampu menjadi muslimah dengan akhlak yang baik.

Pesan Dakwah pada Teks 3 “Demokrasi Sekuler Makin Menyuburkan dan Melindungi Para Penista Agama"

Pesan dakwah yang terkandung di dalamnyaadalah pesan aqidah. Pesan akidah tentang memahami Islam secarah kaffah. Yang terdapat pada QS. an-Nisa: 59). "Hai orang-orang yang beriman, taatilah Allah dan taatilah Rasul (Nya), dan ulil amridi antara kamu. kemudian jika kamu berlainan Pendapat tentang sesuatu, Maka kembalikanlah ia kepada Allah (Al Quran) dan Rasul (sunnahnya), jika kamu benar-benar beriman kepada Allah dan hari kemudian. yang demikian itu lebih utama (bagimu)dan lebih baik akibatnya".

\section{Penutup}

a. Kesimpulan

Setelah menganalisa dan mendeskripsikan data dan diperkuat dengan wawancara langsung kepada Ahmad Sastra, selaku pemilik dan penulis artikel dari AhmadSastra.com, maka pada bab penutup ini peneliti mengambil kesimpulan yang disajikan dalambentuk tabel dan uraian berikut:

Tabel 1. Kesimpulan berdasar analisis teks

\begin{tabular}{lll}
\hline No & Konstruksi Teks & Kesimpulan \\
\hline 1 & Tematik & $\begin{array}{l}\text { Memamparkan maksuddan makna yang ditekankan pada } \\
\text { setiaptemanya dengan baik }\end{array}$ \\
\hline 2 & Skematik & Terstruktur \\
\hline 3 & Semantik & Ditampilkan dengan cukup detail \\
\hline 4 & Sintaksis & Sering menggunakan bentuk kalimat induktif \\
\hline 5 & Leksikon & Bahasa yang digunakan ringan agar mudah dipahami \\
\hline
\end{tabular}

Tabel 2. Kesimpulan berdasar konteks dan kognisi sosial

\begin{tabular}{ll}
\hline KonstruksiTeks & Kesimpulan \\
\hline & Dari segi kognisi dan konteks sosial, bahwa Rubrik Opini Aktual \\
& AhmadSastra.com memiliki konsentrasi khusus terhadap isu-isu yang sedang \\
& hanya diperbincangkan khalayak. Hal ini selain sebagai upaya dakwah yang \\
& dipilih oleh penulis, adalah penulis memiliki kewajiban untuk mengingatkan \\
& sesama muslim akan Islam. Melihat bidang dan rekam jejak beliau selama ini, \\
& dapat menjadi kontrol sosial di tengah Negara yang berpenduduk mayoritas \\
& Muslim terbesar di dunia untuk giat dalam menambah wawasan dan \\
& membuka kajian-kajian diskusi keilmuan dan mempopulerkan dunia literasi \\
& Islam \\
\hline
\end{tabular}

Wacana teks dalam Rubrik Opini Aktual AhmadSastra.com dikonstruksi dan dilihat dari dimensi teks Teun Van Dijk, antara lain: Teks ini mampu memaparkan maksud dan makna yang ditekankan pada setiap temanya dengan baik. Seperti dari segi skematik yang terstruktur, elemen semantik yang digambarkan dengan cukup detail, sintaksis yang kebanyakan menggunakan bentuk induktif sehingga mampu membuat pembaca penasaran untuk membaca hingga tuntas, dan leksikon yang dipilih pun adalah bahasa yang lumayan mudah dicerna walaupun tema yang 
disajikan terkadang cukup berat dan butuh kajian lebih lanjut. Dari segi kognisi dan konteks sosial, bahwa Rubrik Opini Aktual Ahmad Sastra memiliki fokus khusus terhadap pemikiran dan dakwah Islam serta merespon cepat isu-isu keummatan yang tengah hangat diperbincangkan.

Tabel 3. Kesimpulan berdasar konteks dan kognisi sosial

\begin{tabular}{|c|c|}
\hline Teks & Pesan Dakwah \\
\hline 1 & Pesan Akidah dan Syarial \\
\hline 2 & $\begin{array}{l}\text { Hijrah, Radikal,Teroris, Bendera Hitam, Pancasila, Al-Qur'an,Pesan Akidah,Syariah, dar } \\
\text { Soekarno,dan Nabi Muhammad } \\
\text { S Akhlak }\end{array}$ \\
\hline 3 & $\begin{array}{l}\text { Demokrasi SekulerMakin Menyuburkan dan Melindungi Para Pesan Akidah } \\
\text { Penista Agama }\end{array}$ \\
\hline
\end{tabular}

\section{b. Saran}

Setelah peneliti melakukan penelitian pada website AhmadSastra.com dan menganalisis hasilnya, peneliti mempunyai saran atau rekomendasi. Semoga rekomendasi ini dapat meningkatkan kualitas konten dakwah pada website AhmadSastra.com. Berikut saran-saran yang akan penulis sampaikan, yang diharapakan menjadi bahan masukan dan pertimbangan terkait pihak- pihak yang membutuhkan.

1. Untuk para mahasiswa jurusankomunikasi, analisis wacana merupakanmetode penelitian yang sedang berkembang di Indonesia. Namun masih minim literatur khususnya dalam bahasa Indonesia. Oleh karena itu, peneliti yakin bahwa penelitian ini akan sangat bermanfaat untuk dijadikan referensi bagi penelitian dengan metode yang sama selanjutnya.

2. Untuk para $d a^{\prime} i$ atau kalangan akademisi muslim yang mendalami kajian dakwah melalui tulisan, khususnya pada fokus pemikiran Islam. Maka, dianjurkan untukmembaca website Ahmad Sastra.com. Wacana dan isi yang terdapat didalamnya sangat bagus untuk menambah khazanah keilmuan tentang pemikiran Islam dan sangat bagus untuk dijadikan bahan kajian dan diskusi keilmuan.

3. Untuk situs AhmadSastra.com sebaiknya lebih diperhatikan lagi sistematika penulisan dalam tanda baca dan kalimat aktif. Juga, desain website yang jangan terlalu tekstual. Dikarenakan realita masyarakat saat ini lebih menyukai tampilan yang nyaman dilihat.

\section{Daftar Pustaka}

Aan, Komarih \& Djam'an, Satori. (2014). Metodologi penelitian kualitatif. Alfabeta.

Abdul Aziz, Abdullah. (2007). Cara mudah memahami aqidah sesuai Al-Qur'an, As-Sunnah, dan pemahaman salafus shalih. Pustaka At-Tazkia.

Abdullah, Rohi. (2015). Web programing is easy. Elek Media Komputindo.

Abdullah. (2019). Ilmu dakwah kajian ontologi, epistemologi, aksiologi, dan aplikasi dakwah. PT. RajaGrafindo Persada.

Alexa Internet. https://id.m.wikipedia.org/wiki/Alexa_Internet

Ali Aziz, Mohammad. (2009). Ilmu dakwah. Prenada Media.

Amin, Samsul Munir. (2009) Ilmu Dakwah. Amzah.

Aziz, Mohammad. (2004). Ahli ilmu dakwah. Prenada Media.

Bekti, Bintu Humairah. (2015). Mahir membuat website dengan adobe dreamweaver CS6, CSS dan jquery. Andi. 
Betha, Sidik. (2014). Pemrograman Web denganPHP. Santika Kencana.

Bungin, Burhan. (2006). Sosiologi Komunikasi. Kencana Prenada Media Group.

Kamus Besar Bahasa Indonesia. (2020). http://kbbi.web.id/

Mahmud, Yunus. (1990). Kamus Arab Indonesia.Mahmud Yunus Wa Dzurriyyah.

Munir \& Wahyu Ilahi. (2006). Manajemendakwah. Prenada Media.

Munir, Syamsul Amin. (2008). Rekonstruksi pemikrian dakwah Islam. Amzah.

Nasrullah, Rulli. (2016). Media sosial perspektifkomunikasi, budaya, sosioteknologi. Simbiosa Rekatama Media.

Nasrullah, Rulli. (2017). Media sosial perspektifkomunikasi, budaya, sosioteknologi. Simbiosa Rekatama Media.

Pendidikan Nasional, Departemen. (2002). KamusBesar Bahasa Indonesia. Balai Pustaka.

Pendidikan Nasional, Departemen. (2008). KamusBesar Bahasa Indonesia edisi keempat. Gramedia Pustaka Utama.

Perdagangan RI, Kementrian. (2014). Panduan Optimalisasi Media Sosial untuk Kementrian Perdagangan RI. Tim Pusat Humas Kementrian Perdagangan RI Pusat.

Peter Salim \& Yenny Salim. (2002). Kamus BesarBahasa Indonesia Kontemporer. Modern English Press.

Prastowo, Andi. (2011). Metode penelitian kualitatif dalam perspektif rancangan penelitian. Ar Ruzz Media.

Saleh, Setiadi. (2010). 30 menit mengenal Islam. Cicero Publishing.

Saputra, Wahidin. (2011). Pengantar ilmu dakwah. PT. Raja Grafindo Persada.

Sari, R. R. N., \& Ariefana, P. (2018). Kontroversi Bendera Tauhid, Jubir: HTI Tidak Punya Bendera. $\quad$ https://amp.suara.com/news/2018/10/25/120508/kontroversi-bendera-tauhidjubir-hti-tidak-punya-bendera

Sobur, Alex. Analisis teks media; suatu pengantaruntuk analisis wacana, semiotik dan analisis framming. Remaja Rosdakarya.

Sugiyono, (2007). Metode penelitian kuantitatifkualitatif dan $R \& D$. Alfabeta.

Sugiyono. (2015). Metode penelitian kombinasi(mix methods). Alfbeta.

Suhandang, Kustadi. (2013). Ilmu dakwah perspektif komunikasi. PT. Remaja Rosdakarya.

Sumadiria, Haris. (2005). Menulis artikel dan tajukrencana. Simbiosis Rekatama Media.

Toto, Tasmara. (1997). Komunikasi dakwah. Gaya Media Pratama.

Wikipedia. (2020). Wikipedia.id 